\title{
Pengaruh Parameter Proses Milling pada Austempered Ductile Iron (ADI) terhadap Kekasaran Permukaan Benda Kerja dan Chip Thickness Ratio
}

\author{
Rusnaldy $^{1 *}$, Yusuf Umardani1 ${ }^{1}$, Diva Tsamara Putra ${ }^{1}$, Jovian Bernard ${ }^{1}$ \\ ${ }^{1}$ Departemen Teknik Mesin Fakultas Teknik Universitas Diponegoro \\ Jl. Prof. Soedarto, S.H., Kampus Undip Tembalang, Semarang \\ *E-mail: rusnaldy@yahoo.com
}

Diterima: 17-03-2021; Direvisi: 02-08-2021; Dipublikasi: 27-08-2021

\begin{abstract}
Abstrak
Austempered ductile iron (ADI) adalah salah satu material yang sulit dilakukan proses permesinan walaupun ADI diyakini memiliki beberapa keunggulan seperti kekuatan, keuletan, ketangguhan yang tinggi, ketahanan lelah, ketahanan aus dinamik yang baik, memiliki rasio kekuatan-berat yang baik, mudah dibuat dan mudah dicor yang menyebabkannya banyak digunakan di berbagai aplikasi. Studi ini meneliti pengaruh parameter proses terhadap kekasaran permukaan dan chip thickness ratio yang dihasilkan dari proses milling pada ADI. ADI dibuat dengan cara memanaskan ductile iron ke temperatur austenit di dalam suatu tungku heat treatment pada temperatur $900^{\circ} \mathrm{C}$ selama 1 jam dan kemudian dimasukkan ke dalam larutan garam yang bertemperatur $375^{\circ} \mathrm{C}$ selama 1 jam. Proses milling dilakukan dengan menggunakan tool dari karbida dengan diameter $20 \mathrm{~mm}$. Proses milling dilakukan tanpa menggunakan carian coolant atau dry cutting. Kecepatan makan yang digunakan bervariasi dari 0,05 hingga 0,1 $\mathrm{mm} /$ tooth untuk kecepatan potong dengan range $15 \mathrm{~m} /$ menit hingga $25 \mathrm{~m} /$ menit dan kedalaman potong dengan range 0,1 mm hingga 0,3 mm. Kekasaran permukaan diukur dengan menggunakan alat uji kekasaran Mitutoyo SJ-201. Ketebalan geram diukur dengan menggunakan software Image $\mathbf{J}$ dari foto geram yang dihasilkan oleh mikroskop endoskopi digital. Hasil yang diperoleh menunjukkan bahwa geram yang dihasilkan dari studi ini adalah geram berbentuk connected dan loose. Pengaruh kecepatan potong, kecepatan makan dan kedalaman potong dilaporkan dan didiskusikan dalam makalah ini.
\end{abstract}

Kata kunci: ADI; proses milling; kekasaran permukaan; bentuk geram; chip thickness ratio

\begin{abstract}
Austempered ductile iron (ADI) is a difficult material for machining, even though ADI is believed to have several advantages such as strength, ductility, high toughness, fatigue resistance, good dynamic wear resistance, has a good strength-to-weight ratio, easy to manufacture and easy to cast that causes it to be widely used in various applications. This study investigates the effect of milling parameters on surface rougness and chip thickness ratio on milling of ADI. To produce ADI, ductile irons were first austenitized in furnace at $900^{\circ} \mathrm{C}$ for 1 hour and then they were quenched in salt bath at $375^{\circ} \mathrm{C}$ for 1 hour. The work material was machined with uncoated carbide tool. The tool was $20 \mathrm{~mm}$ in diameter. The cutting experiments were carried out in the dry mode. The feed was varied from 0.05 to $0.1 \mathrm{~mm} /$ tooth for cutting speed ranging from $15 \mathrm{~m} / \mathrm{min}$ to $25 \mathrm{~mm} / \mathrm{min}$ and depth of cut ranging from $0.1 \mathrm{~mm}$ to $0.3 \mathrm{~mm}$. The surface roughness was measured using the Mitutoyo SJ-201, surface roughness machine. The chip thickness was measured using software Image J from the photograph produced by digital microscope endoscope. The results show that connected and loose chips were produced. Long and continuous chips were not found in this study. The effects of cutting speeds, feeds and depth of cut on surface roughness and chip thickness ratio are reported in this paper
\end{abstract}

Keywords: ADI; milling process; surface roughness; chip form; chip thickness ratio

\section{Pendahuluan}

Austempered ductile iron (ADI) saat ini telah dapat digunakan sebagai material pengganti untuk baja cor, baja tempa (forging) dan bahkan paduan aluminium di berbagai aplikasi [1]. ADI diyakini memiliki beberapa keunggulan yang menyebabkannya banyak digunakan diberbagai aplikasi seperti kekuatan, keuletan, ketangguhan yang tinggi, ketahanan lelah dan ketahanan aus dinamik yang baik serta memiliki rasio kekuatan-berat yang baik, mudah dibuat dan 
Rusnaldy dkk /Jurnal Rekayasa Mesin p-ISSN: 1411-6863, e-ISSN: 2540-7678 Vol.16|No.2|200-209|Agustus|2021

mudah dicor [2-5]. ADI adalah besi cor yang memiliki grafit bulat yang diperoleh melalui proses isothermal heat treatment. Sifat mekanik yang baik dari ADI disebabkan karena adanya struktur ausferritic yang mengandung ferit (acicular ferrite) dan karbon jenuh pada austenit [6-7] dan sifat mekanik yang diperoleh juga tergantung pada parameter perlakuan panas, ukuran dan distribusi grafit bulat yang ada, struktur mikro yang dihasilkan dan ada atau tidaknya cacat yang dihasilkan selama proses pengecoran berlangsung [8-9].

Dalam proses permesinan, ADI termasuk material yang memiliki sifat mampu mesin (machinability) yang rendah [10]. Pahat potong mudah mengalami aus, baik flank wear maupun crater wear. Ini disebabkan karena ADI memiliki sifat mekanik yang baik seperti telah disebutkan sebelumnya. Hal ini menjadi tantangan tersendiri bagi produsen pembuatan komponen dari ADI. Karena walau bagaimana untuk membuat produk akhir yang memiliki dimensi yang sesuai dengan gambar teknik, komponen dari ADI kerap mengalami proses akhir berupa proses permesinan. Proses permesinan yang paling banyak digunakan pada ADI adalah proses milling.

Proses permesinan telah dicoba pada ADI oleh beberapa peneliti dalam beberapa eksperimen [11-17]. Cakir dkk. mencoba melakukan penelitian untuk mengetahui machinability ADI yang telah mengalami proses tempering pada variasi temperatur dan waktu temper [11]. Machinability diukur berdasarkan keausan pahat dan gaya potong yang terjadi selama proses permesinan berlangsung. Hasilnya menunjukkan bahwa peningkatan kekerasan ADI akan mempercepat terjadinya keausan dan terjadinya peningkatan gaya potong. Klocke dkk. juga meneliti keausan pahat ketika digunakan untuk memotong ADI [12]. Pahat potong yang digunakan pada proses permesinan ADI terlihat lebih cepat aus karena terjadinya keausan abrasive dan adhesive yang cukup besar. Secara umum menggunakan kedalaman potong akan memperbaiki machinibality dari logam yang dilakukan proses permesinan. Hal ini tidak terjadi ketika kedalaman potong diturunkan untuk memotong ADI. Rendahnya kedalaman potong yang digunakan tidak memperbaiki machinability dari ADI [13]. Sementara itu, de Carvalho dkk. mencoba membandingkan machinability ADI dengan grade yang berbeda, yaitu ASTM grade 2 dan 3 dengan kekerasan berturut-turut 29 HRC dan 40,5 HRC [14]. Dari hasil yang diperoleh terlihat bahwa ADI grade 2 memiliki umur pahat lebih rendah sebesar 33\% dibanding grade 3. Akibat tingginya tingkat keausan pahat ketika memotong ADI, sehingga perlu diteliti pengaruh penggunaan coolant. Sakharkar dan Pawade mencoba menggunakan kondisi permesinan yang berbeda ketika memotong ADI, yaitu tanpa coolant (kering), Minimum Quantity Lubrication (MQL) dan flood coolant [15]. Dari hasil yang diperoleh terlihat bahwa kondisi pemotongan dengan MQL memiliki tingkat keausan pahat yang lebih baik serta kekasaran permukaan yang juga baik bila dibandingkan dengan kondisi pemotongan kering dan flood coolant. Penelitian lain mencoba membandingkan machinability antara ADI dan baja cor pada kondisi MQL, yang hasilnya memperlihatkan bahwa keausan pahat dan gaya potong yang terjadi pada ADI jauh lebih besar dibanding baja cor. Namun kekasaran permukaan yang terjadi pada ADI lebih baik bila dibanding dengan baja cor.

Dari uraian tersebut terlihat bahwa belum banyak peneliti yang meneliti pengaruh parameter proses permesinan terhadap kekasaran permukaan yang dihasilkan pada proses milling. Untuk itu, pada makalah ini diuraikan bagaimana pengaruh paramater proses milling seperti kecepatan potong, kecepatan makan dan kedalaman potong terhadap kekasaran permukaan yang dihasilkan. Kekasaran permukaan adalah salah satu fitur penting dari suatu produk hasil permesinan karena akan terkait dengan ketahanan lelah produk, terutama pada produk yang akan mengalami beban dinamik. Geram yang dihasilkan juga diamati dan dianalisa bentuknya serta chip thickness ratio dihitung sebagai indikasi dari sifat machinability ADI. Benda kerja ADI diperoleh dari proses pengecoran besi cor nodular yang dilanjutkan dengan melakukan proses heat treatment. 
Rusnaldy dkk /Jurnal Rekayasa Mesin

p-ISSN: 1411-6863, e-ISSN: 2540-7678

Vol.16|No.2|200-209|Agustus|2021

\section{Material dan Metodologi}

\subsection{Proses pembuatan besi cor nodular}

Bahan baku yang digunakan berasal dari drum bekas. Ukuran dari drum cukup besar sehingga perlu dilakukan proses press terlebih dahulu dengan menggunakan mesin press agar dapat dimasukkan ke dalam tungku yang digunakan untuk proses peleburannya. Selama proses peleburan, dilakukan proses magnesium treatment untuk membuat grafit berbentuk bulat atau nodul. Temperatur lebur untuk proses magnesium-treatment adalah sekitar $1538^{\circ} \mathrm{C}-1565^{\circ} \mathrm{C}$. Logam cair kemudian dituang ke dalam cetakan berukuran 100 x 100 × 30 mm. Cetakan yang digunakan berbahan dasar pasir kering yang menggunakan pengikat dari waterglass. Ketika besi cor dimasukkan ke dalam cetakan, besi cor diberi hembusan gas $\mathrm{CO}$ untuk membantu proses pengintian kristal pada material tersebut. Logam cair yang berada di dalam cetakan kemudian didinginkan dengan menggunakan pendinginan udara.

\subsection{Proses pembuatan ADI}

Proses pembuatan ADI melalui 2 tahap proses perlakuan panas, yaitu pemanasan dan penahanan pada suhu austenisasi serta quenching yang dilakukan pada salt bath dengan penahanan pada suhu $375^{\circ} \mathrm{C}$. Besi cor nodular yang dihasilkan dari proses pengecoran digunakan sebagai benda kerja untuk proses ini. Peralatan yang harus disiapkan antara lain tungku (furnace) dan tungku salt bath. Adapun set-up dari proses pembuatan austempered ductile iron (ADI) dapat dilihat pada gambar 1.

Proses pemanaan pada suhu austenisasi dilakukan di dalam tungku (furnace) pada suhu $900^{\circ} \mathrm{C}$ dan ditahan pada suhu tersebut selama $1 \mathrm{jam}$. Kemudian benda kerja dipindahkan ke dalam media berisi salt bath yang bersuhu $375^{\circ} \mathrm{C}$ selama 1 jam. Jenis garam yang digunakan pada salt bath adalah garam $\mathrm{KNO}_{3}$. Setelah itu dilakukan proses pendinginan di udara terbuka.

\subsection{Proses milling}

Dimensi benda kerja yang digunakan pada proses milling adalah 50 × 50 × $30 \mathrm{~mm}$. Mesin milling yang digunakan adalah Aciera F4 Milling Machine. Sedangkan pahat yang digunakan untuk memotong permukaan benda kerja adalah jenis pahat end mill yang terbuat dari karbida yang memiliki diameter sebesar $20 \mathrm{~mm}$ dan 4 flute. Kecepatan makan yang digunakan bervariasi dari 0,05 hingga $0,1 \mathrm{~mm} /$ tooth untuk kecepatan potong dengan range $15 \mathrm{~m} / \mathrm{menit}$ hingga 25 $\mathrm{m} / \mathrm{menit}$ dan kedalaman potong dengan range $0,1 \mathrm{~mm}$ hingga $0,3 \mathrm{~mm}$. Proses milling yang dilakukan tanpa menggunakan cairan coolant atau dry cutting.

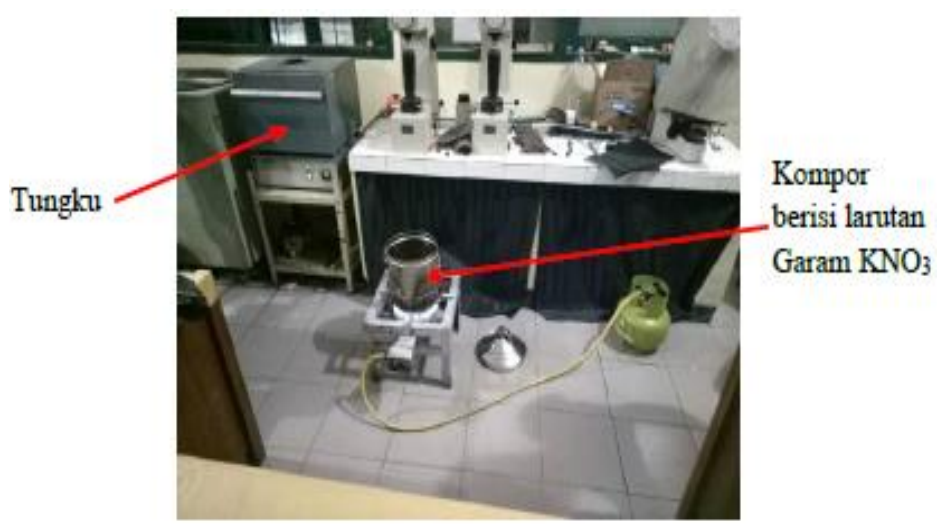

Gambar 1. Proses pembuatan ADI 
Rusnaldy dkk /Jurnal Rekayasa Mesin p-ISSN: 1411-6863, e-ISSN: 2540-7678

Vol.16|No.2|200-209|Agustus|2021

\subsection{Pengamatan dan pengujian}

Pengamatan struktur mikro dilakukan dengan menggunakan mikroskop Meiji Techno IM7200. Mikroskop ini memiliki 2 lensa, yaitu lensa okuler dan lensa obyektif. Perbesaran yang dapat dihasilkan dapat mencapai 100x pada lensa obyektif dan 10x pada lensa okuler, sehingga perbesaran maksimum yang dapat dihasilkan oleh mikroskop sebesar 1000x. Mikroskop yang digunakan terhubung dengan lensa lumenera infinity 1. Lensa ini terintegrasi dengan software infinity analyze sehingga gambar yang dihasilkan dapat dilihat pada monitor komputer dan disimpan dalam bentuk file. Set up pengamatan struktur mikro dapar dilihat pada Gambar 2. Pengamatan struktur mikro dilakukan pada spesimen sebelum dilakukan austempering dan pada spesimen austempered ductile iron (ADI).

Pengukuran kekasaran permukaaan benda kerja hasil proses milling dilakukan dengan menggunakan alat uji kekasaran Mitutoyo SJ-201. Set up pengujian kekasaran permukaan dapat dilihat pada Gambar 3. Hal yang paling penting sebelum proses pengukuran dilakukan adalah penentuan sampling length. Pada studi ini sampling length yang digunakan adalah $2,5 \mathrm{~mm}$.

Pengamatan geram dilakukan dengan mengamati bentuk geram dan mengukur ketebalan geram hasil proses milling. Pengamatan bentuk geram dilakukan dengan mengambil sampel geram pada tiap parameter hasil proses milling dan pengukuran ketebalan geram dilakukan dengan menggunakan alat uji mikroskop endoskopi digital. Set up pengukuran dapat dilihat pada Gambar 4. Mikroskop yang digunakan dapat dikoneksikan ke komputer untuk melihat langsung geram yang diamati dengan perbesaran yang diinginkan. Pengukuran ketebalan geram dapat dilakukan dengan membuka gambar geram yang diperbesar tadi dengan menggunakan software aplikasi ImageJ. Hasil pengukuran ketebalan digunakan untuk menentukan chip thickness ratio.

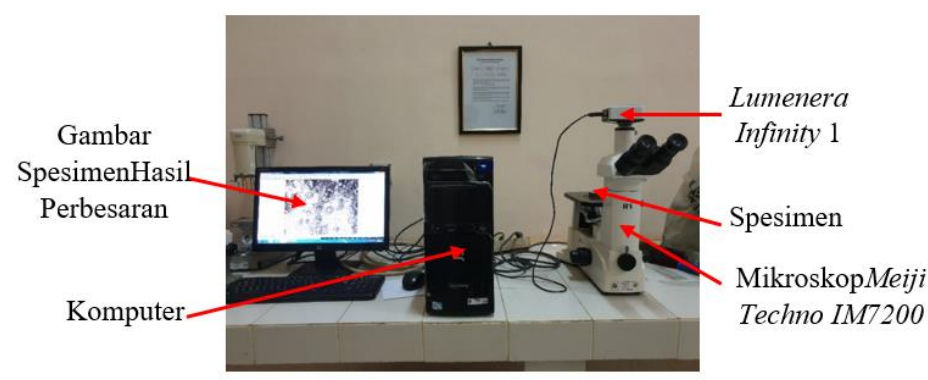

Gambar 2. Set up pengamatan struktur mikro

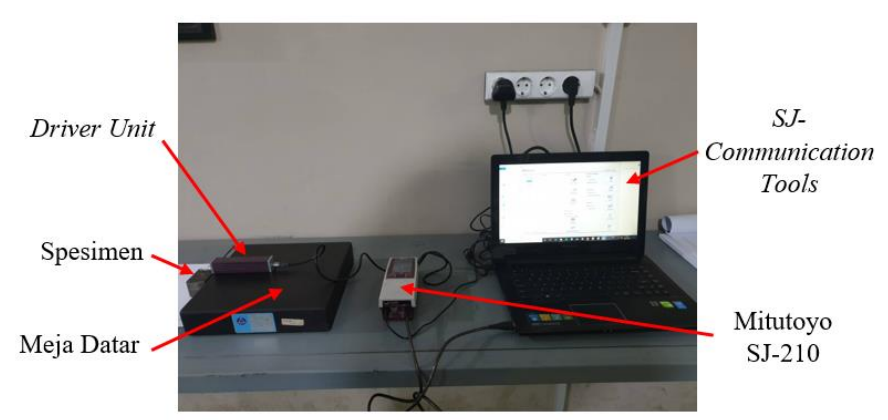

Gambar 3. Set up pengukuran kekasaran permukaan 
Rusnaldy dkk /Jurnal Rekayasa Mesin

p-ISSN: 1411-6863, e-ISSN: 2540-7678

Vol.16|No.2|200-209|Agustus|2021

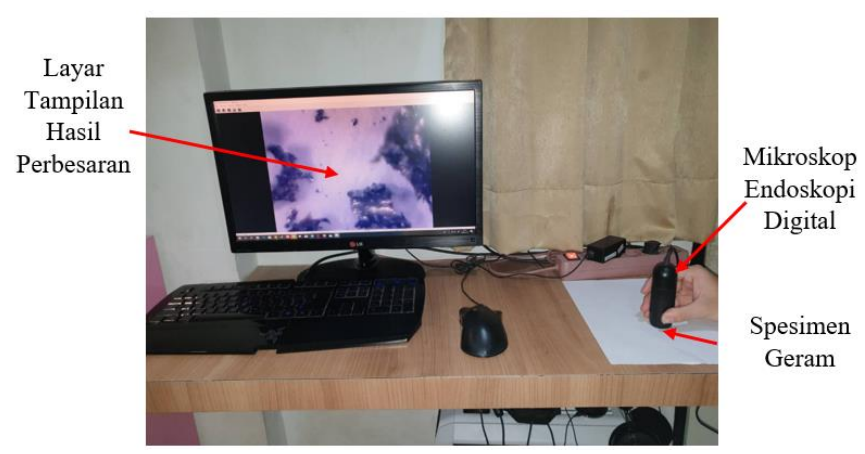

Gambar 4. Set up pengukuran ketebalan geram

\section{Hasil dan Pembahasan}

Gambar 5 adalah foto struktur mikro besi cor nodular sebelum dilakukan proses etsa. Dari gambar tersebut terlihat adanya grafit berbentuk bulat yang menandakan proses magnesium treatment berhasil dilakukan. Gambar 6 adalah foto struktur mikro ADI sebelum dan setelah dilakukan proses etsa. Terlihat pada gambar 6 di sebelah kanan bahwa terdapat permukaan yang berwarna putih yang berada di sekeliling grafit dan hal tersebut merupakan matriks ferit. Disamping itu juga terlihat adanya matriks ausferit yang berwarna terang, sedangkan yang berwarna gelap merupakan matriks bainit. Dari hasil pengukuran dimensi nodul yang dilakukan dengan software lumenera infitiny 1 diperoleh ukuran nodul rata-rata sebesar 47,81 - 64,91 $\mu \mathrm{m}$. Ukuran nodul ADI terlihat lebih besar bila dibanding ukuran rata-rata nodul pada besi cor nodular yang berukuran 35,70 - 39,59 $\mu \mathrm{m}$. Dari hasil pengujian kekerasan diperoleh nilai rata-rata kekerasan ADI (378,56 HV) lebih besar dibanding dengan nilai kekeraan besi cor nodular (206,27 HV). Hasil ini membuktikan bahwa ADI memang jauh lebih baik sifat mekaniknya dibanding dengan besi cor nodular. Hal ini sesuai dengan data yang telah ada yaitu kekuatan tarik ADI ( $930 \mathrm{MPa}$ ) jauh lebih tinggi dibanding besi cor nodular (535 MPa) [17] dan ADI juga memiliki kekerasan (42 HRC) yang lebih tinggi disbanding besi cor nodular (23 HRC) [18].

Kekasaran permukaan suatu permukaan benda kerja dari hasil proses permesinan tergantung dari geometri pahat, material pahat, metarial benda kerja, parameter proses dan kondisi proses permesinan yang menggunakan coolant atau kering [19]. Pengaruh parameter proses permesinan terhadap rata-rata kekasaran permukaan benda kerja hasil proses milling dapat dilihat pada Gambar 7 - 9. Gambar 7 menunjukkan pengaruh kecepatan potong terhadap kekasaran permukaan di permukaan benda kerja. Dari gambar terlihat dengan naiknya kecepatan potong dari $15 \mathrm{~m} / \mathrm{min}$ ke 25 $\mathrm{m} /$ min kekasaran permukaan yang dihasilkan akan menjadi semakin kecil atau halus. Pengurangan kekasaran permukaan yang terjadi sebesar 3,8\%. Hasil ini sesuai dengan apa yang pernah dilakukan oleh Secer dan Hasirci, dimana pada penelitian mereka disimpulkan bahwa semakin besar nilai kecepatan potong, maka terjadi penurunan nilai kekasaran permukaan [20].

Sementara itu, peningkatan kecepatan makan dan kedalaman potong berakibat pada naiknya kekasaran permukaan benda kerja yang dihasilkan. Peningkatan kekasaran permukaan dari kecepatan makan 0,05 menjadi $0,1 \mathrm{~mm} /$ tooth sebesar 26,5\%, sementara itu peningkatan kedalam potong dari 0,1 hingga $0,3 \mathrm{~mm}$ hanya menyebabkan peningkatan kekasaran permukaan sebesar 8,3\%. Secara umum kekasaran permukaan yang terbaik dihasilkan pada parameter proses permesinan dimana kecepatan potongnya sebesar $15 \mathrm{~m} / \mathrm{min}$, kecepatan makan sebesar 0,05 mm/tooth dan kedalaman potong sebesar 0,1 $\mathrm{mm}$. Dari hasil terlihat kecepatan makan adalah parameter yang paling dominan yang menyebabkan besar kecilnya kekasaran permukaan. Hal ini ditunjukkan dengan besarnya kenaikan kekasaran permukaan yang cukup signifikan, yaitu sebesar $26,5 \%$. 
Rusnaldy dkk /Jurnal Rekayasa Mesin

p-ISSN: 1411-6863, e-ISSN: 2540-7678

Vol.16|No.2|200-209|Agustus|2021

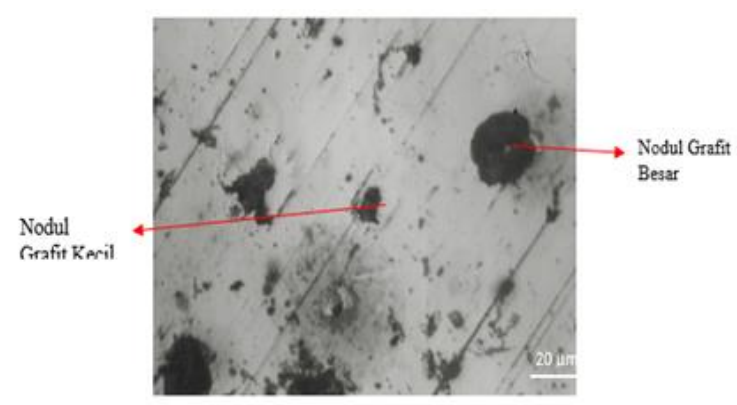

Gambar 5. Grafit bulat pada besi cor nodular

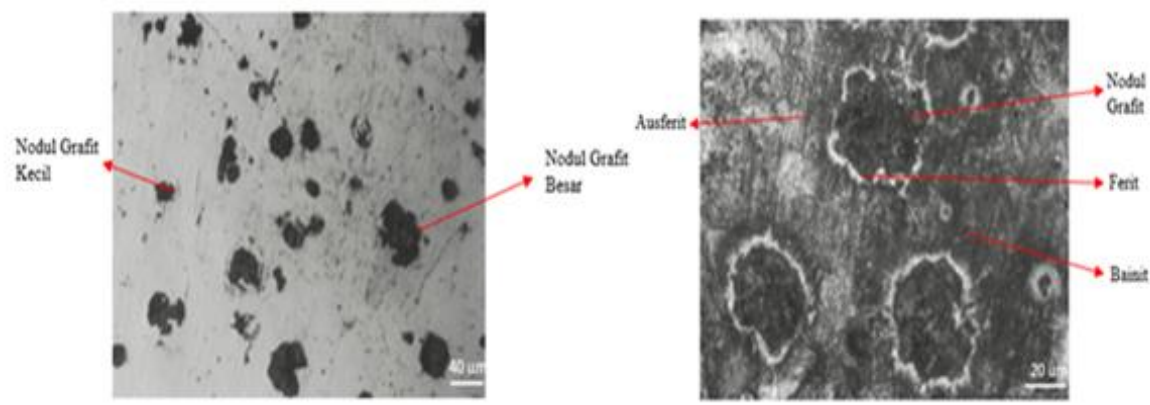

Gambar 6. Struktur mikro ADI sebelum (kiri) dan setelah proses etsa (kanan)

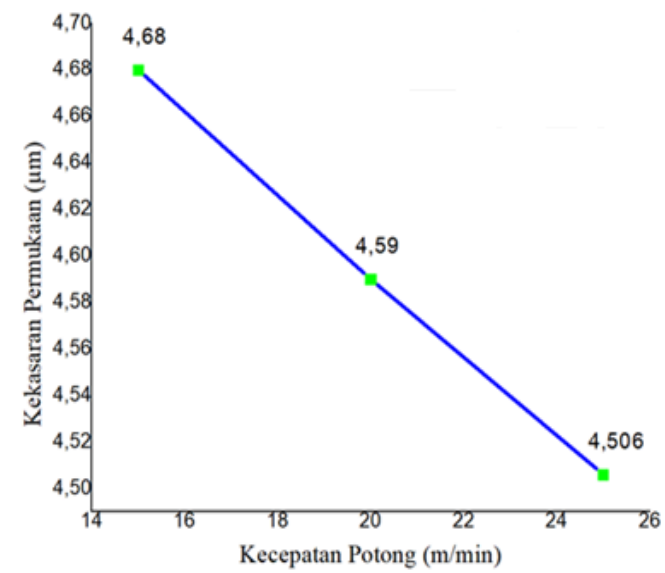

Gambar 7. Pengaruh kecepatan potong terhadap kekasaran permukaan

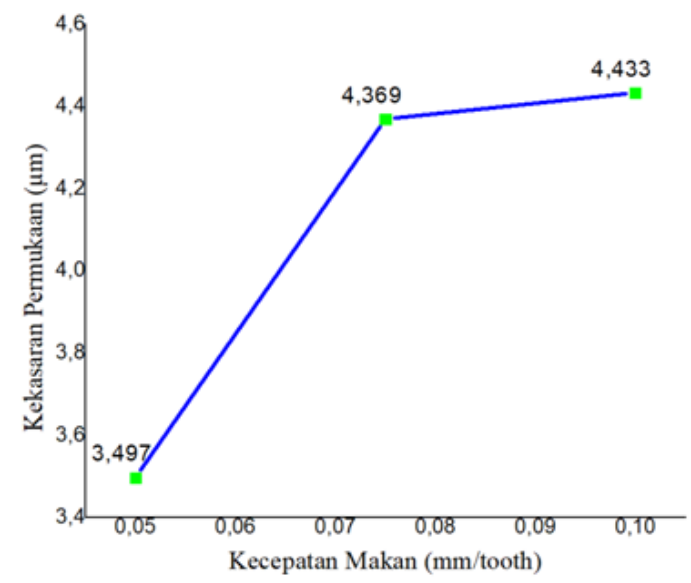

Gambar 8. Pengaruh kecepatan makan terhadap kekasaran permukaan 
Rusnaldy dkk /Jurnal Rekayasa Mesin

p-ISSN: 1411-6863, e-ISSN: 2540-7678

Vol.16|No.2|200-209|Agustus|2021

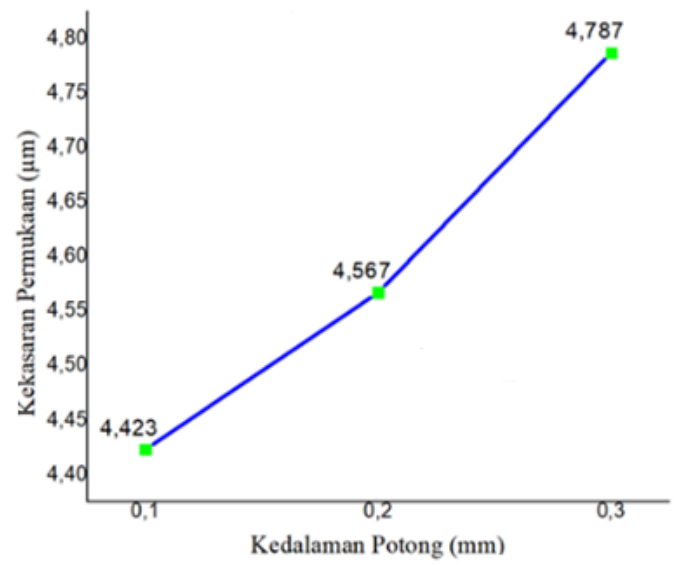

Gambar 9. Pengaruh kedalaman potong terhadap kekasaran permukaan

Gambar 10 menunjukkan bentuk geram yang dihasilkan dari beberapa parameter proses milling. Foto geram dilakukan dengan menggunakan mikroskop endoskopi digital dengan perbesaran 50x. Jika mengacu pada Kalpakjian [21], geram yang dihasilkan pada proses milling ini memiliki bentuk kontinyu yang melingkar dan tidak terputus serta tidak kontinyu. Menurut standar ISO 3685 [22], geram yang dihasilkan semuanya masuk kategori jenis arc chips. Geram jenis arc chips terbagi menjadi dua, (i) connected seperti yang terlihat pada Gambar 7 bagian atas dan (ii) loose seperti yang terlihat pada Gambar 7 bagian bawah. Bentuk geram loose dihasilkan dari proses milling dengan menggunakan kecepatan makan yang rendah, sementara bentuk geram connected dihasilkan dari kecepatan potong tinggi dan kecepatan makan yang tinggi. Hal ini dapat mengindikasikan bahwa bentuk geram yang dihasilkan didominasi oleh parameter kecepatan makan yang digunakan.

Untuk menghitung chip thickness ratio, perlu dilakukan pengukuran tebal geram hasil proses milling. Pada setiap parameter hasil proses milling pengukuran tebal geram dilakukan pada masing-masing tiga sampel geram yang berbeda. Setelah didapatkan nilai ketebalan geram untuk setiap parameter hasil pemotongan, maka selanjutnya penghitungan chip thickness ratio (CTR) dapat dihitung menggunakan rumus pada persamaan (1)[21]:

Di mana:

$$
R c=\frac{t_{o}}{t_{c}}
$$

$\mathrm{R}_{\mathrm{c}} \quad$ : Chip Thickness Ratio (CTR)

$\mathrm{t}_{\mathrm{o}} \quad$ : Tebal geram sebelum proses milling $(\mathrm{mm})$

$t_{c} \quad:$ Tebal geram setelah proses milling $(\mathrm{mm})$

Tebal geram sebelum proses milling dihitung dengan rumus pada persamaan (2) [23]:

$$
t_{0}=f \cdot \sin K A P R
$$

Di mana:

f : Kecepatan makan $(\mathrm{mm} /$ tooth $)$

KAPR : Entering angle $\left({ }^{\circ}\right)$

Entering angle yang digunakan pada studi ini adalah $90^{\circ}$. 
Rusnaldy dkk /Jurnal Rekayasa Mesin

p-ISSN: 1411-6863, e-ISSN: 2540-7678

Vol.16|No.2|200-209|Agustus|2021
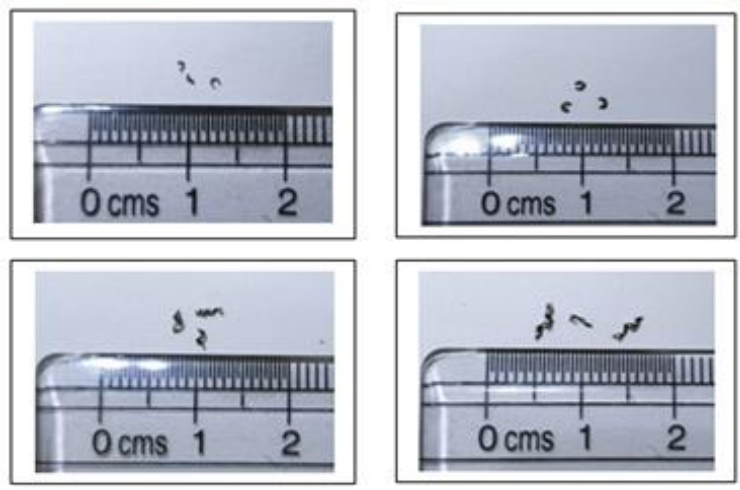

Gambar 10. Bentuk geram yang dihasilkan dari proses milling

Gambar 11 menunjukkan pengaruh kecepatan makan dan kedalaman potong terhadap besarnya CTR yang dihasilkan. Dari gambar-gambar tersebut terlihat bahwa naiknya kecepatan makan akan menyebabkan turunnya CTR dan CTR akan naik seiring dengan naiknya kedalaman potong. CTR dapat digunakan sebagai indikasi machinability dari benda kerja. Jika nilai CTR turun maka daya yang dibutuhkan untuk proses milling akan semakin besar, getaran yang mungkin terjadi saat proses milling berlangsung juga semakin besar dan permukaan benda kerja akan menjadi semakin kasar. Hasil ini sesuai dengan nilai kekasaran permukaan yang didapat pada parameter kecepatan makan namun tidak sesuai dengan nilai kekasaran permukaan yang didapat pada kedalaman potong. Kajian lebih detil akan dilakukan untuk melihat ketidaksesuaian ini.

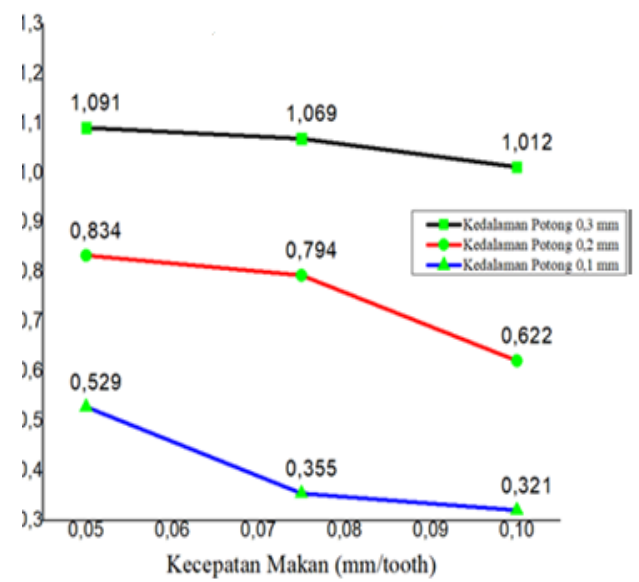

Gambar 11. Pengaruh kecepatan makan terhadap chip thickness ratio pada berbagai kedalaman potong

\section{Kesimpulan}

Dari hasil yang diperoleh dapat disimpulkan bahwa naiknya kecepatan potong menyebabkan pengurangan kekasaran permukaan sebesar 3,8\% pada permukaan hasil milling dengan benda kerja ADI. Sementara itu, peningkatan kekasaran permukaan sebesar 26,5\% terjadi ketika kecepatan makan ditingkatkan dan peningkatan kedalam potong menyebabkan peningkatan kekasaran permukaan sebesar 8,3\%. Dari hasil terlihat kecepatan makan adalah parameter yang paling dominan yang menyebabkan besar kecilnya kekasaran permukaan untuk proses milling ADI. Geram yang dihasilkan pada studi ini adalah jenis arc chips dengan bentuk connected dan loose. Bentuk geram loose dihasilkan dari 
Rusnaldy dkk /Jurnal Rekayasa Mesin p-ISSN: 1411-6863, e-ISSN: 2540-7678 Vol.16|No.2|200-209|Agustus|2021

proses milling dengan menggunakan kecepatan makan yang rendah, sementara bentuk geram connected dihasilkan dari kecepatan makan tinggi dan kedalaman potong yang tinggi. Hal ini dapat mengindikasikan bahwa kecepatan makan adalah faktor yang dominan yang mempengaruhi bentuk geram yang dihasilkan pada proses milling ADI. Chip thickness ratio akan turun ketika kecepatan makan dinaikkan dan chip thickness ratio akan naik seiring dengan naiknya kedalaman potong.

\section{DaftarPustaka}

[1] B. Wang, F. Qiu, G.C. Barber, Y. Pan, W. Cui, R. Wang., Microstructure, Wear Behavior and Surface Hardening of Austempered Ductile Iron. Journal of Materials Research and Technology. 2020; 9: p. 98389855.

[2] Hatate M, Shiota T, Takahashi N, Shimizu K., Influence of graphite shapes on the wear characteristics of austempered cast iron.Wear. 2001; 251: p. 885-889.

[3] Rebasa N, Dommarco R, Sikora J., Wear resistance of high nodule count ductile iron. Wear. 2002; 253: p. 855-861.

[4] Magalhaes L, Seabra J., Wear and scuffing of austempered ductile iron gears. Wear. 1998; 215: p. 237-246.

[5] S.Samaddar, T.Das, A.K.Chowdhury, M.Singh., Manufacturing of Engineering components with Austempered Ductile Iron - A Review. Materials Today: Proceedings. 2018; 5: p. 25615-25624.

[6] Artola G, Gallastegi I, Izaga J, Barrena M, Rimmer A., Austempered ductile iron (ADI) alternative material for high-performance applications. International Journal of Metalcasting 2017; 11(1): p.131-135.

[7] Kiguchi S, Magata A., Effect of $\mathrm{C}$ and $\mathrm{Si}$ on mechanical properties of austempered ductile iron. International Journal of Cast Metals Research 2011; 14: p. 53-58.

[8] K. Aslantas, S.Tasgetiren, Y. Yalcın., Austempering retards pitting failure in ductile iron spur gears. Engineering Failure Analysis. 2004; 11: p. 935-941.

[9] K. Aslantas, S.Tasgetiren., A study of spur gear pitting formation and life prediction. Wear. 2004; 257: p. 11671175

[10] P. Parhad, V. Dakre, A. Likhite, J,. Bhatt. The impact of cutting speed and depth of cut on cutting force during turning of austempered ductile iron. Materials Today: Proceedings. 2019; 19: p. 663-669.

[11] M. C. Cakir., A. Bayram, Y. Isik, B. Salar., The effect of austempering and time onto machinability of austempered ductile iron. Materials Science and Engineering A. 2005; 407: p. 147-153.

[12] F. Klocke, C. Klopper, D. Lung, C. Essig., Fundamental wear mechanisms when machining austempered ductile iron (ADI). Annals of the CIRP. 2007; Vol. 56: 1: p. 73-76.

[13] B. Avishan, S. Yazdani, D. J Vahid., The influence of depth of ct on the machinability of an alloyed austempered ductile iron. Materials Science and Engineering A. 2009; 523: p. 93-98.

[14] M. V. de Carvalho, D. M. Montenegro, J. O. Gomes., An analysis of the machinability of ASTM grades 2 and 3 austempered ductile iron. Journal of Material Processing Technology. 2013; 213: p. 560-573.

[15] S. N. Sakahrkar, R. S. Pawade., Effect of machining environment on turning performance of austempered ductile iron. CIRP Journal of Manufacturing Science and Technology. 2018; 22: p. 49-65.

[16] D. Eraslan, A. Balci, B. Cetin, N. Ucak, A. Cicek, O. D. Yilmaz, K. Davut., Machinability evaluations of austempered ductile iron and cast steel with similar mechanical properties under eco-friendly milling conditions. Journal of Materials Research and Technology. 2021; 11: p. 1443-1456. 
Rusnaldy dkk /Jurnal Rekayasa Mesin p-ISSN: 1411-6863, e-ISSN: 2540-7678

Vol.16|No.2|200-209|Agustus|2021

[17] _, ASM Metals Handbook, Vol 1, Properties and selection: Irons, Steels and High Performance Alloys, $10^{\text {th }}$ edition. ASM International: 1993: p. 86.

[18] K. Aslantas, S. Tasgetiren., A study of spur gear pitting formation and life prediction. Wear. 2004; 257: p. 11671175.

[19] _, ASM Metals Handbook, Vol 16, Machining Processes, $9^{\text {th }}$ edition. ASM International: 1989: p. 4.

[20] U. Seker, H. Hasrici., Evaluation of asutempered ductile irons in terms of cutting forces and surface quality. Journal of Materials Processing Technology. 2006; 173: p. 260-268.

[21] S. Kalpakjian, S.R. Schmid., Manufacturing Engineerin and Technology, 7th edition. Singapore: Pearson Education South Asia Pte Ltd: 2014.

[22] _, ISO 3685 - Tool life testing with single-point turning tools, 2nd edition. Switzerland: ISO, 1993.

[23] https://www.sandvik.coromant.com (diakses 20 Juli 2020) 